\title{
Identification by Light Microscopy of Blastocystis Sp. in Oysters Crassotrea Virginica
}

\author{
Ignacio Martínez-Barbabosa 1,2, Manuel Gutiérrez Quiróz¹, Leticia Ruiz González¹, Adela Luisa Ruiz Hernández ${ }^{1}$ \\ ${ }^{1 *}$ Departamento de Microbiología y Parasitología. Facultad de Medicina. Universidad Nacional Autónoma de México. Avenida Universidad 3000 \\ Ciudad Universitaria, Del. Coyoacán. Ciudad de México. 04510 México. \\ ${ }^{2}$ Departamento de Atención a la Salud. Área de Ciencias Básicas. Laboratorio de Parasitología Humana. Universidad Autónoma de Metropolitana-Xo- \\ chimilco.Calzada del Hueso 1100. Col. Villa Quietud. Del. Coyoacán. Ciudad de México. C.P. 04960. México.
}

\begin{abstract}
*Correspondence to: I. Martínez-Barbabosa. Departamento de Atención a la Salud. Laboratorio de Parasitología Médica. Universidad Autónoma MetropolitanaXochimilco. Calzada del Hueso 1100. Colonia Villa Quietud, Del. Coyoacán C.P. 04960. México City; Tel: +52 5483-7558. Fax: +52 5483-7218; E-mail: imarti@correo. xoc.uam.mx
\end{abstract}

Received: November 22, 2017; Accepted: December 06, 2017; Published: December 12, 2017;

\begin{abstract}
Blastocystis sp., is an anaerobic unicellular microorganism frequently found in the gastrointestinal tract of humans and of a wide gamma species of vertebrate and invertebrate animals. However, its presence in oysters has not been reported, and if the consumption of oysters infected with Blastocystis sp. it is a way of acquiring the infection for humans. The objective of this study was to determine by light microscopic analysis the presence of Blastocystis sp in oysters Crassostrea virginica (C. virginica) sold for human consumption in markets in Mexico City. 500 oysters were obtained. The intestine of each oyster was dissected and the faecal material was examined. The faeces were examined by light microscopic. 77\% were infected with cysts of Blastocystis sp. Eaten raw, these oysters are a possibility source of infection for humans.
\end{abstract}

Key words: C. virginica, oyster, Blastocystis hominis, Blastocystis sp.

\section{Introduction}

Blastocystis sp. is a single-celled, genetically heterogeneous prost, phylogenetically placed within the Stramenopiles a common inhabitat of the human intestinal tract [1]. It is also found in a diverse array of the other vertebrates incluyin pigs, cow, chickens, and reptiles and has a worldwide distribution, highlighting both its low host specific and zoonotic potential. The parasitazation by Blastocystis is considered a zoonosis with fecal-oral transmission route. [2-4].

Blastocystis sp. is probably the most common intestinal protozoan detected in human faecal samples worldwide. The infection occurs in immunocompetent and immunosuppressed individuals [5-7]. The prevalence of Blastocystis sp. in humans, it can be higher than $5 \%$ in developed countries and as high as $76 \%$ in developing countries [8]. In Mexico, young children with low weight showed a prevalence of $80 \%$ [9]. Transmission is fecal-oral, as is the case with other intestinal protozoa. The man acquires the infection especially of food and water contaminated with cysts of Blastocystis sp. coming from a carrier. [10-12]

Blastocystis sp. They multiply asexually by binary fission, endodiogenesis, schizogony, and plasmotomy. They are spherical cells, commonly presents four different morphological forms: vacuolated form, granular form, amoeboid form and cyst form. The vacuolated form is of variable size measuring from 5 to $30 \mu$ it has a large central vacuole that occupies 50 to $95 \%$ of the cell surrounded by a peripheral band of the cytoplasm with several nuclei and numerous mitochondria. It is the predominant form in the gastrointestinal tract. The amoeboid form presents pseudopodia and has great phagocytic activity. The granular form has a large amount of mitochondria that give it a granular appearance [6]. The diagnosis is made with the usual coprologic studies; the most usual is the direct examination in fresh in preparations stained with lugol that allows to identify mainly the cystic form.

The epidemiology of Blastocystis sp. it is still enigmatic and controversial in some aspects. The transmission is done by fecaloral route, similar to what happens with other intestinal protozoa transmitted by fecalism. However, the consumption of live animals infected with Blastocystis sp. It has not yet been determined as a way of transmitting the microorganism to humans. In a previous study oriented to the search of parasites in oyster different species of oysters, we observed several cells morphologically similar to cysts of Blastocystis sp. Find that motivated the realization of the present investigation.

\section{Objective}

Identify, by light microscopy, cellular forms similar to Blastocystis sp. in oysters' C. virginica. 


\section{Material and methods}

\section{Study design}

In the first semester of 2017, a cross-section descriptive sampling was carried out in order to detect cells morphological similar a Blastocystis sp. C. virginica oysters collected in Mexico City.

\section{Study area}

Mexico City that has $8,851,080$ inhabitants and is located at parallels $19^{\circ} 36^{\prime}$ and $19^{\circ} 03^{\prime}$ north of the equator, and at $98^{\circ} 57^{\prime}$ and $99^{\circ}$ $22^{\prime}$ 'west of the Greenwich Meridian, at an altitude 2,240 meters (7,350 $\mathrm{ft})$, with humid temperate climate and average annual temperature $16^{\circ}$ C. The city consists of 16 administrative delegations distributed on the territory of 1,485 square kilometers (573 sq mi) [13].

\section{Collection of specimens}

500 oysters of the genus C. virginica from the Gulf of Mexico were collected in different markets of Mexico City. All the samples were carefully washed with individual brushes and sterile distilled water before being opened. Subsequently, each oyster was placed individually in a sterile Petri dish to identify and dissect the intestine. Next, the intestinal contents were extracted.

\section{Microscopic identification of Blastocystis sp.}

Two smears were made with the intestinal content of each oyster on two different slides. In one case analysis was carried out by direct examination of faeces using a sterile saline isotonic solution at $0.85 \%$ and stained with lugol. The other was stained with Gomori trichrome for detailed identification of the morphology of Blastocystis [14]. The identification of Blastocystis was performed on a Carl Zeiss microscope at 100 and $400 \mathrm{x}$ and cell counts for each microscopic field were taken.

\section{Results}

Morphological Identification of Blastocystis sp was carried out using a Carl Zeiss microscope light at 100 and 400x. Of the $500 C$. virginica oysters analyzed by microscopic identification, $77 \%$ were infected with cysts of Blastocystis sp.

The cystic form was observed. Within, granules with more stain were seen in some discontinuous zones on the periphery and also fixed to the circumference as a thin membrane in discontinuous areas. The central body, of rather indefinite form, displaced the cytoplasm (Figure 1).

In Figure 2, another cyst of Blastocystis sp. can be seen stained with Gomori isolated from fresh faeces. It is clearer than the previous one stained with lugol. The peripheral granules, of which one is of notable size, are seen more clearly. The central body is more clearly defined. The Gomori staining also permits the observer to see a large central vacuole that occupies more than $70 \%$ of the cytoplasm. Furthermore, it compresses the cytoplasm to the cell periphery. Its size can be calculated as $7 \mu \mathrm{m}$. The vacuolar morphology of Blastocystis can be clearly appreciated in Figure 3 .

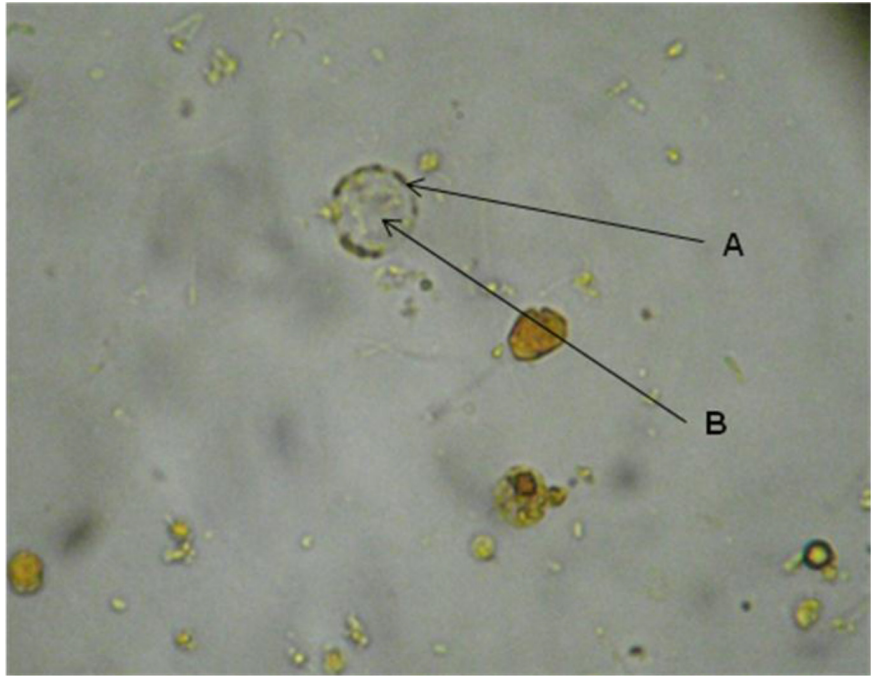

Figure 1. Blastocystis $s p$. cyst in the faeces of $C$. virginica stained with lugol. A. Peripheral granules. B. Central body.

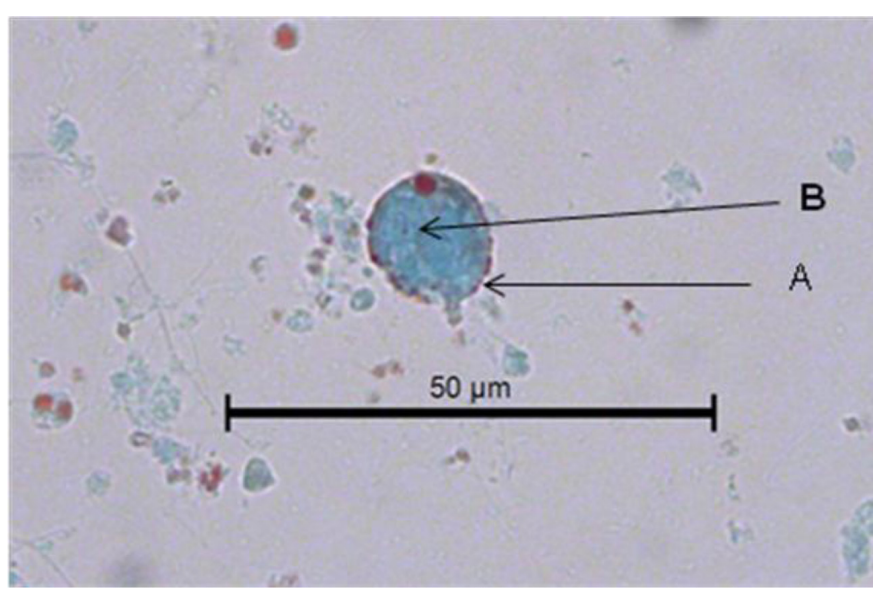

Figure 2. Image of a Blastocystis sp. cyst in the faeces of $C$. virginica stained with Gomori. A. Peripheral granules. B. Central body.

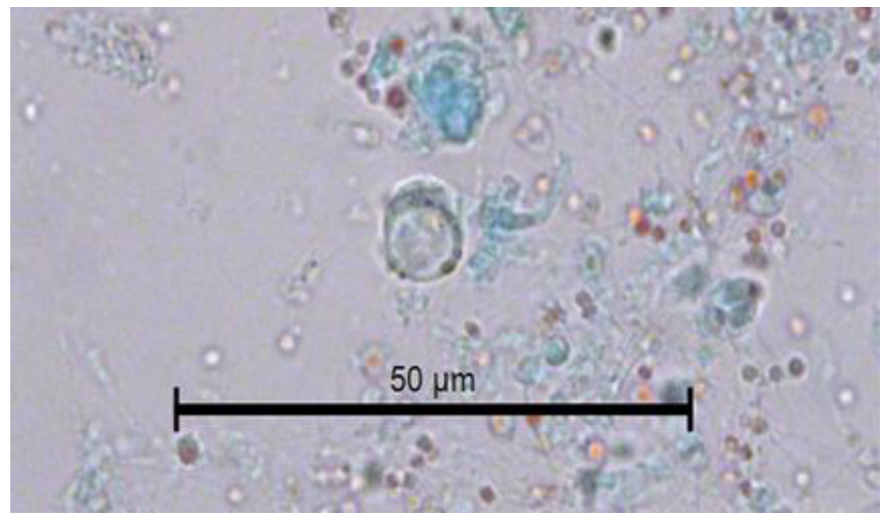

Figure 3. Image of the vacuolar form of Blastocystis sp. in the faeces of $C$. virginica stained with Gomori. 


\section{Discussion}

Worldwide, the production, export and consumption of seafood represents a very high source of economic income in different countries. In Mexico, oyster exploitation is one of the most important fishing activities. The Gulf of Mexico generates $90 \%$ of the national oyster production. It occupies the fourth place in the production of oysters in Latin America [15]. The American Oyster C. virginica is one of the members of the Family Ostreiaidae of greater commercial importance. The oyster is grown from the Gulf of San Lorenzo in Canada to the Laguna de Términos in the state of Campeche, Mexico.

In Mexico City, the oyster C. virginica cultivated mainly in the coastal lagoons of the states of Tabasco and Veracruz is consumed. In this area, the semi-cultivation of $C$. virginica native to the Gulf of Mexico is carried out through collection of wild seed and aquaculturefishing management in natural banks. The production of the oyster in the state of Tabasco takes place in the lagoon systems in the municipalities of Cardenas and Mecoatan. In the state of Veracruz, C. virginica is cultivated in the Tamiahua lagoon, considered as an important oyster reserve of America, located between the coordinates $21^{\circ} 06^{\prime}$ and $22^{\circ} 05^{\prime}$ of North latitude and the $97^{\circ} 23^{\prime}$ and $97^{\circ} 46^{\prime}$ in length; it produces 400 thousand tons annually. A large part of this production is exported to different countries [16].

The raw consumption of raw oysters infected with Blastocystis sp. it implies a potential risk of zoonotic infection and consequently of developing blastocistosis $[17,18]$. Intestinal disease characterized by severe diarrhea, the symptoms attributable to $B$. hominis include: diarrhea, abdominal pain, nausea, vomiting, flatulence, fatigue, anorexia, leading to dehydration and significant weight loss. Generally, fecal leukocytes are not found and in some cases eosinophilia and chronic urticaria have been observed. In immunosuppressed people the symptoms can be progressive; there is a greater tendency to chronicity $[19,20]$.

From the epidemiological point of view, the consumption of raw oysters infected with Blastocystis sp. it represents a risk for the consumer, due to its great ability to adapt to the ecological conditions of the environment in which they live, they could adapt to the physiological conditions provided by the human intestine, and in this way get to reproduce in it becoming a reservoir and source of infection to acquire the disease. This is the first report in which he mentions C. virginica as a reservoir of Blastocystis sp. in oysters grown in the Mexican Republic.

In conclusion, a high prevalence of infection by Blastocystis sp. was determined, in the oyster $C$. virginica the cyst was the predominant form in the oysters examined. The consumption of raw oysters infected with Blastocystis sp. represents a potential risk for the consumer of acquiring blastocystosis. Risk in which the most susceptible population is the undernourished and that with some type of immunodeficiency.

\section{References}

1. Silberman JD, Sogin ML, Leipe DD, Clark CG (1996) Human parasite finds taxonomic home. Nature 380: 398. [crossref]
2. Scanlan PD (2012) Blastocystis: past pitfalls and future perspectives. Trends Parasitol 28: 327-334. [crossref]

3. Santín M, Gómez-Muñoz Mt. Solano-Aquilar G, Fayer R. Development of a new PCR protocol to detect and subtype Blastocystis spp. from humans and animals. Parasitol Res 109: 205-12

4. Parija SC, Jeremiah S (2013) Blastocystis: Taxonomy, biology and virulence. Trop Parasitol 3: 17-25. [crossref]

5. Clark CG, van der Giezen M, Alfellani MA, Stensvold CR (2013) Recent developments in Blastocystis research. Adv Parasitol 82: 1-32. [crossref]

6. Stensvold CR, Suresh GK, Tan KS, Thompson RC, Traub RJ, et al. (2007) Terminology for Blastocystis subtypes--a consensus. Trends Parasitol 23: 93-96. [crossref]

7. Yoshikawa H, Koyama Y, Tsuchiya E, Takami K (2016) Blastocystis phylogeny among various isolates from humans to insects. Parasitol Int 65: 750-759.

8. Tueki H, Hamedi Y, Heidari-Hengami M, Najafi-Asl M, Rafati S, Sharifi- Sarasiabi (2017) Prevalence of intestinal parasitic infection among primary school children in southern Iran. J Parasitol Dis 41: 659-665.

9. Martínez-Barbabosa I, Gutiérrez-Quiroz M, Ruiz-González L, Ruiz-Hernández AL, Gutiérrez-Cárdenas EM (2010) Blastocystis hominis y su relación con el estado nutricional de escolares en una comunidad de la sierra de Huayacocotla, Veracruz, México. Rev Biomed 21: 77-84.

10. Kaya S, Cetin ES, AridoÄŸan BC, Arikan S, Demirci M (2007) Pathogenicity of Blastocystis hominis, a clinical reevaluation. Turkiye Parazitol Derg 31: 184-187. [crossref]

11. Lee LI, Chye TT, Karmacharya BM, Govind SK (2012) Blastocystis sp.: waterborne zoonotic organism, a possibility? Parasit Vectors 5: 130. [crossref]

12. Batista L, Pérez Jove J, Rosinach M, Gonzalo V, Sainz E, et al. (2017) Low efficacy of metronidazole in the eradication of Blastocystis homimis in symptomatic patients; case series and systematic literature review. Gastroenterol Hepatol 40: $381-387$.

13. INEGI (2015) Instituto Nacional de Geografía Estadística e Informática Centro de Población y Vivienda.

14. Sheenan DJ, Raucher BG, McKitrick JC (1986) Association of Blastocystis hominis with signs and symptoms of human disease. J Clin Microbiol 24: 548-550.

15. Maeda-Martínez, AN (2008) Estado actual del cultivo de bivalvos en México. In: Lovatelli A, Farías A, Uriarte I. (ed.), Taller Regional de la FAO sobre el Estado actual del cultivo y manejo de moluscos bivalvos y su proyección futura: factores que afectan su sustentabilidad en América Latina. Actas de Pesca de la FAO, No. 12, Roma 91-100.

16. Contreras EF, Castañeda LO (2000) Las lagunas costeras y estuarios del Golfo de México: hacia el establecimiento de índices ecológicos. En: Diagnóstico ambiental del Golfo de México. INE-SEMANAT. México D.F.

17. Parkar U, Traub RJ, Kumar S, Mungthin M, Vitali S, et al. (2007) Thompson RC. Direct characterization of Blastocystis from faeces by PCR and evidence of zoonotic potential. Parasitology 134: 359-367.

18. Poirier P, Wawrzyniak I, Vivarès CP, Delbac F, El Alaoui H (2012) New insights into Blastocystis spp.: a potential link with irritable bowel syndrome. PLoS Pathog 8: e1002545. [crossref]

19. Toro MEM, Vichido LMA; Montijo BE, Cervantes BR, Zárate MF, et al. (2017) Blastocystis hominis and Chronic Abdominal Pain in Children: Is there an Association between Them? J Trop Pediatr

20. Mauss J, Retz M, Dilts R, Langland J (2017) Multiple sampling and SAFFixative Triple-Faeces Testing for Dysbiosis and Pathogenic Infections of the Gastrointestinal Tract: Case Report. Altern Ther health Med.

\section{Citation:}

Ignacio Martínez-Barbabosa, Manuel Gutiérrez Quiroz, Leticia Araceli Ruiz González, Adela Luisa Ruiz Hernández (2017) Identification by Light Microscopy of Blastocystis Sp. in Oysters Crassotrea Virginica. Integr J Vet Biosci Volume 1(2): 1-3 